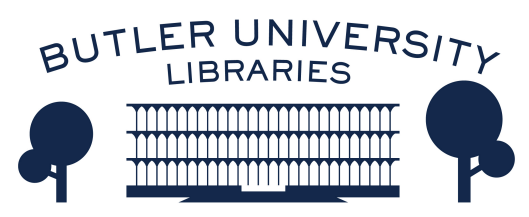

Journal of Hindu-Christian Studies

Volume 8

Article 12

January 1995

\title{
Book Review: "The Crucified Guru: An Experiment in Cross- Cultural Christology"
}

David Carpenter

Follow this and additional works at: https://digitalcommons.butler.edu/jhcs

Part of the Religion Commons

\section{Recommended Citation}

Carpenter, David (1995) "Book Review: "The Crucified Guru: An Experiment in Cross-Cultural Christology"," Journal of Hindu-Christian Studies: Vol. 8, Article 12.

Available at: https://doi.org/10.7825/2164-6279.1117

The Journal of Hindu-Christian Studies is a publication of the Society for Hindu-Christian Studies. The digital version is made available by Digital Commons @ Butler University. For questions about the Journal or the Society, please contact cbauman@butler.edu. For more information about Digital Commons @ Butler University, please contact digitalscholarship@butler.edu. 
Hindus of this century and is not serving them well.

- Vivekananda's downgrading of scriptural scholarship to mere intellectual theory, requiring supplementation by the samādhi of räjayoga, has led to the glossing over of differences of doctrine as unimportant (e.g. differences between Sankhya and Advaita, between Hinduism and other religions). It asserts too easily that all religions lead to the same goal (p.135). The uncritical embracing of this view has not served Hinduism well in the religious pluralism of the twentieth century, for it fails to take difference seriously - something Sankara always did. It has led to a lack of rigour in scholarship (since intellectual differences do not really matter) and to a failure to take the differences between religions seriously. While Vivekananda's attempt to respond to the nineteenth-century challenge of science was commendable, his solution of replacing Sankara's faith in śruti with an uncritical embracing of samādhi as the only valid religious knowledge has left Hinduism with a flawed legacy that needs critical reexamination. Rambachan's book is a first and most important step in this direction.

Harold Coward

University of Victoria

\section{The Crucified Guru: An Experiment in Cross-Cultural Christology M. Thomas Thangaraj. Nashville: Experiment in Cross-Cultural Christology. Nashville: Abingdon Press, 1994.}

M. THOMAS THANGARAJ's Experiment in Cross-Cultural Christology is a thoughtprovoking attempt to apply the Śaiva Siddhānta concept of guru to the interpretation of the significance of Jesus as the "crucified guru". A South Indian Christian, Thangaraj is presently the Ruth and D. W. Brooks Associate Professor of World Christianity at the Candler School of Theology. In his book he draws upon his own intimate knowledge of South Indian spirituality (both Christian and Śaiva) to suggest that the Saiva concept of the guru, and not the better known Vaisnava concept of avatara, provides the most useful model for conceiving an Indian Christology, one that is essentially functionalist and sees Jesus not as a divine man but as a teacher who makes God present to his disciples. As an experiment in cross-cultural Christology, aimed primarily at a Tamil audience but of obvious relevance to anyone doing theology in a global context, Thangaraj's book aims at a "mutual transformation" of the terms "guru" and "Christ". After a brief introduction, in which he notes the inadequacy of incarnational language, the insufficiency of doctrinal orthodoxy, and the inappropriateness of absolutistic claims, Thangaraj outlines the Śaiva Siddhānta concept of guru and then surveys earlier uses of the guru concept in Indian Christian discourse. In a rather brief chapter he then attempts "to reconstruct a portrait of Jesus applying the title 'guru' to him" (p.91). This is then followed by an examination of the possibilities and problems raised by this portrait, and a concluding chapter on "The Christological Task Today".

The merit of Thangaraj's book is to have made a very specific proposal that deserves serious consideration. But the exploration of Śaiva Siddhānta and its concept of guru will require more than it receives here to make it fully understood to a western Christian audience. The application of this concept to Jesus, carried out in the shortest chapter of the book, could also benefit from a more extensive discussion. Thus one wishes that Thangaraj had written more, or perhaps that 
his publisher had allowed him to include more. Also, it is not clear exactly what the result of this "mutual transformation" of the concepts "Christ" and "guru" will be. If we truly accustom ourselves to thinking of Jesus as guru, it begins to sound odd to hear of God's "raising Jesus from the dead and appointing him guru for all" (p.103). The very intimacy and local appeal of the guru seems to be undone by requiring that he be the guru "for all". Thangaraj is aware of this, and has in mind a process of mutual critique in which neither concept will remain unchanged. We are given some brief indications of where this will lead: away from traditional Śaiva Siddhānta metaphysics, for example, as well as away from traditional Christian exclusivism and "christolatry". His suggestions are brief and tentative, appropriate perhaps to an initial "experiment". One hopes that Thangaraj will continue his experiment, exploring his richly suggestive if somewhat vague image of Jesus as "crucified guru", and elaborating its implications for both Christians and Hindus in more detail.

David Carpenter

St Joseph's University, Philadelphia

\section{Women of Power and Grace: Nine Astonishing, Inspiring} Luminaries of our Time. Timothy Conway. Santa Barbara, California: The Wake Up Press, 1994. 351 pp.

TIMOTHY CONWAY PRESENTS the tales and teachings of nine women of various faiths whom he describes as "illustrious spiritual leaders" and "profound exemplars of holiness". Conway commences each of his decidedly uncritical examinations of the lives and letters of these women with a short biography, followed in most cases with a digest of quotable quotes.

He starts, appropriately enough, with America's first official saint, Mother Frances Cabrini, whose accomplishments at the turn of the century included a drive for much-needed schools, orphanages, hospitals, social service programs, and convents. Unfortunately he sets a schmaltzy tone that he never shakes throughout the book, the style being a strange blend of obsequiousness and condescension.

This is certainly not an academic study but rather a sentimental review in which Conway makes the perilous assumption that he is preaching to the converted. $\mathrm{He}$ alienates the objective reader in an apparent attempt to appease the disciples of the various women he seeks to exalt. The tales take on the air of folklore and fable. For example, Conway makes the unqualified assertion that the Roman Catholic nun Therese Neumann of Germany ate and drank nothing but a daily Eucharist wafer for 40 years and in the process doubled her weight to over 215 pounds!

Conway describes an Eastern Orthodox "holy fool", Pelagia, who cured people with a witch-like cackle, and Russian Orthodox emigrée to France, Maria Skobtsova, who saved hundreds of lives before herself becoming a casualty in a Nazi death camp. The Muslim Sufi saint Hazrat Babajan fled her native Afghanistan to make her home under a neem tree at Poona, India, where she is credited with healing the sick and the afflicted, and once used her talents at clairvoyance to save lives when fire broke out in a crowded theatre miles away.

But Conway has a particular soft spot for the four Hindu holy women to whom he devotes fully half his book. The Hindu "Guru of gurus", Āndandamayi Mā, had the capacity to dematerialize at will and the ability to carry out spiritual 